\title{
SĄDOWNICTWO POLUBOWNE - KONSTYTUCYJNE ASPEKTY ARBITRAŻU
}

\begin{abstract}
Abstrakt: Sądownictwo polubowne usytuowane poza konstytucyjnie zdefiniowanym wymiarem sprawiedliwości może stanowić istotne uzupełnienie państwowego wymiaru sprawiedliwości. Rozstrzyganie sporów w ramach sądownictwa polubownego wymaga uprzedniego zawarcia między stronami umowy arbitrażowej, będącej wyrazem autonomii woli stron wyłączających jurysdykcję sądu państwowego w zakresie prowadzenia postępowania arbitrażowego $\mathrm{w}$ odniesieniu do wskazanego w umowie przedmiotu sporu. Możliwość rozstrzygania sporów w ramach arbitrażu jest powszechnie akceptowana poprzez nadanie sądom polubownym statusu organów ochrony prawnej. Konstytucja Rzeczypospolitej Polskiej określa zasady gwarantujące obywatelom prawo dostępu do sądu oraz autonomię praw i wolności. Czy zatem funkcjonowanie sądownictwa polubownego pozostaje w zgodzie z podstawowymi zasadami konstytucyjnymi, zwłaszcza jeśli patrzeć na arbitraż przez pryzmat sądownictwa prywatnego i w odniesieniu do konstytucyjnie gwarantowanego sądowego wymiaru sprawiedliwości? Odpowiedź jest twierdząca przy uwzględnieniu, że sądownictwo państwowe uzupełnione sądownictwem polubownym można nazwać nowoczesną przestrzenią sądowej sprawiedliwości.
\end{abstract}

Słowa kluczowe: sądownictwo polubowne, arbitraż, konstytucja, rozstrzyganie sporów, rozwiązywanie konfliktów, wymierzanie sprawiedliwości

\section{WPROWADZENIE}

Sądownictwo polubowne przedstawiane jest w piśmiennictwie jako prywatna metoda rozstrzygania sporów, która może być wybrana przez strony jako alternatywa wobec postępowania przed sądami państwowymi ${ }^{1}$. Arbitraż rozumiany jako sposób rozwiązywania konfliktów zwaśnionych stron wykorzystywany był od wieków, gwarantując stosowanie rozwiązań umożliwiających polubowne rozstrzygnięcie sporu. W procesie kształtowania się prawa dobrodziejstwo polubownego rozstrzygania konfliktów zawsze postrzegane było jako rozwiązanie uczciwe, szlachetne i zdecydowanie lepsze od sądowego wyrokowania w sporach.

1 Ł. Błaszczak, M. Ludwik, Sadownictwo polubowne (arbitraż), Warszawa 2007, s. 1. 
Rozstrzyganie sporów w ramach sądownictwa polubownego wymaga uprzedniego zawarcia między stronami umowy arbitrażowej, będącej wyrazem autonomii woli stron wyłączających jurysdykcję sądu państwowego w zakresie prowadzenia postępowania arbitrażowego w odniesieniu do wskazanego w umowie przedmiotu sporu. Umowa arbitrażowa określana mianem zapisu na sąd polubowny stanowi zatem odzwierciedlenie zamiaru stron poddania sporu istniejącego lub przyszłego, wynikającego z danego stosunku prawnego, pod rozstrzygnięcie sądu polubownego. Zarówno w piśmiennictwie, jak też w utrwalonych poglądach judykatury trafnie przyjmuje się, że zawarcie umowy arbitrażowej określającej poddanie sporu pod rozstrzygnięcie sądu polubownego ma fundamentalne znaczenie dla postępowania arbitrażowego i stąd zapis na sąd polubowny uznaje się za centralną instytucję sądownictwa polubownego ${ }^{2}$. Należy przy tym podkreślić, że przedmiotem umowy arbitrażowej może być istniejący między stronami spór — mamy wtedy do czynienia z klauzulą kompromisarską, mocą której strony poddają już istniejący spór pod rozstrzygnięcie sądu polubownego. Umowa arbitrażowa może również przyjąć formę klauzuli arbitrażowej, zgodnie z którą pod rozstrzygnięcie sądu polubownego poddawane są spory mogące wyniknąć między stronami w przyszłości.

\section{WZAJEMNE RELACJE SĄDOWNICTWA POLUBOWNEGO I SĄDOWNICTWA PAŃSTWOWEGO}

Sądownictwu polubownemu, podobnie jak sądowemu wymiarowi sprawiedliwości sprawowanemu przez sądy powszechne, przypisywany jest adjudykacyjny charakter sprowadzający się do rozstrzygania sporu orzeczeniem stanowiącym decyzję orzeczniczą sądu polubownego, któremu powierzono przeprowadzenie postępowania i rozstrzygnięcie sporu zgodnie z zapisem na sąd polubowny. Wskazana cecha wspólna sądownictwa polubownego i sądownictwa państwowego przesądza zatem o alternatywnej możliwości prowadzenia postępowań arbitrażowych i postępowań sądowych celem rozstrzygnięcia wewnętrznego sporu zaistniałego między stronami decyzją zewnętrznego względem stron organu sądowego. Charakter rozstrzygnięcia odpowiednio wyrokiem sądu polubownego lub wyrokiem sądu powszechnego pozostaje jednak zdecydowanie różny przy uwzględnieniu prywatnego sposobu rozstrzygania przez sąd polubowny i władczego w ramach sprawowania wymiaru sprawiedliwości rozstrzygania przez sąd państwowy.

2 R. Morek, Mediacja i arbitraż (art. $183^{1}-183^{15}, 1154-1217$ k.p.c.). Komentarz, Warszawa 2006, s. 127; Ł. Błaszczak, M. Ludwik, op. cit., s. 76; E. Marszałkowska-Krześ, Kodeks postępowania cywilnego. Komentarz, Warszawa 2015; J. Skoczylas, Charakter prawny zapisu na sąd polubowny a autonomia regulacji prawnej arbitrażu (po nowelizacji z 2005 roku), [w:] Księga pamiątkowa 60-lecia Sąu Arbitrażowego przy Krajowej Izbie Gospodarczej w Warszawie, red. J. Okolski et al., Warszawa 2010, s. 136. 
Wyrazem odrębności sądownictwa polubownego względem sądownictwa państwowego pozostaje niewątpliwie usytuowanie arbitrażu poza konstytucyjnie zdefiniowanym wymiarem sprawiedliwości. Sądownictwo polubowne nie działa jednak w izolacji od państwowego wymiaru sprawiedliwości, bowiem obowiązujące regulacje zakreślają zarówno ramy prowadzenia postępowania arbitrażowego, jak też precyzyjnie zakres sprawowanej nad sądownictwem polubownym kontroli sądowego wymiaru sprawiedliwości. W poglądach doktryny w odniesieniu do umiejscowienia postępowania arbitrażowego za dominujące należy uznać stanowisko wskazujące na zasadność kwalifikacji postępowania przed sądem polubownym w kategoriach pozasądowego postępowania cywilnego ${ }^{3}$. Powszechnie wskazuje się również, że funkcjonowanie sądownictwa polubownego poza sądownictwem powszechnym należy ocenić w kategoriach istotnego uzupełnienia państwowego wymiaru sprawiedliwości ${ }^{4}$. Czy zatem funkcjonowanie sądownictwa polubownego pozostaje w zgodzie z podstawowymi zasadami konstytucyjnymi, zwłaszcza jeśli patrzeć na arbitraż przez pryzmat sądownictwa prywatnego i w odniesieniu do konstytucyjnie gwarantowanego sądowego wymiaru sprawiedliwości?

\section{SĄDY POLUBOWNE JAKO ORGAN OCHRONY PRAWNEJ}

Określenie sądownictwa polubownego w odniesieniu do regulacji Konstytucji Rzeczypospolitej Polskiej ${ }^{5}$ (dalej: Konstytucji) zostało przedstawione w piśmiennictwie i stanowiskach doktryny w szerokim zakresie ${ }^{6}$. Zasadniczo zgodnie wywodzi się, że pomiędzy obowiązującymi przepisami dotyczącymi arbitrażu a regulacjami konstytucyjnymi nie ma kolizji ${ }^{7}$. Wskazuje się jednak, że określenie arbitrażu w relacji do prawa konstytucyjnego w szerokim ujęciu wymaga pogodzenia uniwersalności i bezwzględnego charakteru konstytucyjnego prawa jednostki do ochrony prawnej ze strony państwa oraz elementarnych standardów

3 T. Ereciński, K. Weitz, Są arbitrażowy, Warszawa 2008, s. 23.

4 J. Okolski, Arbitrażu nie wolno sformalizować, „Puls Biznesu” 3.02.2005.

5 Konstytucja Rzeczypospolitej Polskiej z dnia 2 kwietnia 1997roku, Dz.U. z 1997 r. Nr 78, poz. 483 ze zm.

6 Z. Czeszejko-Sochacki, Prawo do sądu w świetle Konstytucji Rzeczypospolitej Polskiej (Ogólna charakterystyka), „Państwo i Prawo” 1997, nr 11-12; J. Gołaczyński, A. Krzywonos, Prawo do sqdu, [w:] Prawa i wolności obywatelskie w Konstytucji RP, red. B. Banaszak, A. Preisner, Warszawa 2002; H. Mądrzak, Prawo do sadu jako gwarancja ochrony praw czlowieka (studium na tle polskiego prawa konstytucyjnego, prawa cywilnego materialnego i procesowego), [w:] Podstawowe prawa jednostki i ich sądowa ochrona, red. L. Wiśniewski, Warszawa 1997; P. Gil, Delegowanie funkcji orzeczniczych na podmioty spoza systemu wymiaru sprawiedliwości — konstytucyjne granice instytucji, [w:] Konstytucjonalizacja postępowania cywilnego, red. Ł. Błaszczak, Wrocław 2015.

7 A. Budniak-Rogala, Charakter prawny zapisu na sad polubowny w postępowaniu cywilnym, Wrocław 2015, s. 37 oraz przywołane tamże poglądy doktryny. 
tej ochrony z przepisami ustawowymi radykalnie ograniczającymi rolę sądów w sporach poddanych arbitrażowi ${ }^{8}$.

Zgodnie z art. 10 ust. 1 Konstytucji ustrój Rzeczypospolitej Polskiej opiera się na podziale oraz równowadze władzy ustawodawczej, władzy wykonawczej i władzy sądowniczej. Z zasady podziału władz wynika, że władza sądownicza ma odrębną pozycję względem legislatury i egzekutywy, nadto pełni funkcję apolitycznego czynnika równowagi, a w odniesieniu do praw i wolności jednostki odpowiednio funkcję apolitycznego gwaranta tych praw ${ }^{9}$. Zasady wykonywania władzy sądowniczej w zakresie wymiaru sprawiedliwości określone zostały $\mathrm{w}$ art. $173 \mathrm{n}$. Konstytucji, z wyszczególnieniem w art. 175 sądów sprawujących wymiar sprawiedliwości, a mianowicie Sądu Najwyższego, sądów powszechnych, sądów administracyjnych i sądów wojskowych. Ponadto w art. 176 przewidziane zostało dwuinstancyjne postępowania sądowe, a w art. 177 określono, że sądy powszechne sprawują wymiar sprawiedliwości we wszystkich sprawach z wyjątkiem tych ustawowo zastrzeżonych dla właściwości innych sądów. Nadmienić przy tym należy, że pojęcie i zakres wymiaru sprawiedliwości rozpatruje się w doktrynie na płaszczyźnie przedmiotowej i podmiotowej. Od strony przedmiotowej eksponuje się rozstrzyganie konfliktów i orzekanie w sprawach przekazanych sądom według właściwości na podstawie obowiązujących regulacji, natomiast względem strony podmiotowej wskazuje się na niezawisłe i bezstronne sądy precyzyjnie wskazane w powołanych regulacjach konstytucyjnych. Warto przy tym pamięć, że żaden przepis Konstytucji nie upoważnia ustawodawcy do delegowania władzy sądowniczej na inny podmiot niż organ sądowy sprawujący wymiar sprawiedliwości. Biorąc pod uwagę, że w powołanych wyżej regulacjach konstytucyjnych nie zostały wymienione sądy polubowne, należy stanowczo stwierdzić, że sądownictwa polubownego nie można zaliczyć ani do organów władzy sądowniczej, ani uznać za inny organ realizujący czynności orzecznicze w ramach sprawowania wymiaru sprawiedliwości. Stanowisko wykluczające możliwość przyznania sądom polubownym władzy rozstrzygania sporów cywilnoprawnych w ramach sprawowania wymiaru sprawiedliwości jest w pełni akceptowane w doktrynie. Przyjmuje się przy tym, że definicja wymiaru sprawiedliwości w ujęciu przedmiotowo-podmiotowym nie obejmuje swoim zakresem działalności sądownictwa arbitrażowego i stąd sądownictwo polubowne należy kwalifikować w kategoriach pozasądowych organów ochrony prawnej, nad którymi pieczę sprawuje sądownictwo powszech$n \mathrm{e}^{10}$. Nadto wskazuje się, że wyłączenie możliwości uznania sądu arbitrażowego za organ państwa skutkuje stwierdzeniem, że sądy polubowne działają zamiast sądów państwowych i jako takie, udzielając ochrony prawnej, realizują zadania, które należą do państwa ${ }^{11}$.

8 A.W. Wiśniewski, Międzynarodowy arbitraż handlowy w Polsce, Warszawa 2011, s. 54-55.

${ }^{9}$ L. Garlicki, Polskie prawo konstytucyjne. Zarys wyktadu, Warszawa 2000, s. 349.

10 Ł. Błaszczak, M. Ludwik, op. cit., s. 51.

11 T. Ereciński, K. Weitz, op. cit., s. 16-18. 
W odniesieniu do przytoczonych poglądów przyznających sądom polubownym status organów ochrony prawnej należy zatem wywieść brak jakichkolwiek przeszkód do realizacji czynności w ramach postępowania arbitrażowego i rozstrzygania sporów w ramach sądownictwa polubownego. Wyłączenie bowiem sądownictwa polubownego zgodnie z powołanymi regulacjami konstytucyjnymi z możliwości sprawowania wymiaru sprawiedliwości oraz przyznanie sądom arbitrażowym statusu pozasądowych organów ochrony prawnej sytuuje sądownictwo polubowne poza konstytucyjnie określonymi ramami sądowego wymiaru sprawiedliwości. W związku z powyższym funkcjonowanie sądów polubownych nie koliduje z konstytucyjnie określonym porządkiem prawnym i to zarówno od strony podmiotowej instytucjonalnego funkcjonowania sądów arbitrażowych, jak też od strony przedmiotowej w zakresie rozstrzygania sporów powierzonych sądom polubownym. Należy zatem w pełni podzielić wyrażony w piśmiennictwie pogląd, że działalność sądów polubownych nie jest ani wyjątkiem od zasady konstytucyjnego wymiaru sprawiedliwości, ani też nie stanowi przełamania monopolu sądów państwowych na sprawowanie wymiaru sprawiedliwości ${ }^{12}$.

\section{KONSTYTUCYJNE RAMY SĄDOWEGO WYMIARU SPRAWIEDLIWOŚCI}

Zgodność poglądów doktryny w zakresie przyznania sądom polubownym statusu pozasądowych organów ochrony prawnej bez kolizji z sądownictwem państwowym w zakresie konstytucyjnie określonych ram sprawowania wymiaru sprawiedliwości nie przekłada się jednak bezpośrednio na ocenę funkcjonowania sądownictwa polubownego w odniesieniu do konstytucyjnej zasady gwarantującej obywatelom prawo dostępu do sądu. Zgodnie z art. 45 ust. 1 Konstytucji każdy ma prawo do sprawiedliwego i jawnego rozpatrzenia sprawy bez nieuzasadnionej zwłoki przez właściwy, niezależny, bezstronny i niezawisły sąd, nadto zgodnie z art. 77 ust. 2 Konstytucji ustawa nie może nikomu zamykać drogi sądowej dochodzenia naruszonych wolności i praw. Powołane przepisy niewątpliwie wzajemnie się uzupełniają, tworząc spójną regulację gwarantującą realizację prawa do sądu jako samoistnego prawa podmiotowego. Przyjęta w powołanych przepisach zasada dostępu obywateli do sądu określona została w orzecznictwie Trybunału Konstytucyjnego jednym z fundamentalnych założeń demokratycznego państwa prawa rozumianym jako gwarancja umożliwienia obywatelom obrony ich interesów przed niezawisłym organem kierującym się wyłącznie obowiązującym $\mathrm{w}$ państwie prawem ${ }^{13}$. Powszechnie przyjmuje się w doktrynie i orzecznictwie,

12 Ibidem, s. 20.

13 Por. uzasadnienie wyroku Trybunału Konstytucyjnego z dnia 12 marca 2002 roku, P 9/01, OTK-A z 2002 r. nr 2, poz. 14. 
że na konstytucyjne prawo do sądu składają się w szczególności: prawo dostępu do sądu (prawo uruchomienia procedury), prawo do odpowiedniego kształtowania procedury (zgodnie z wymogami sprawiedliwości i jawności) oraz prawo do wyroku sądowego (prawo do uzyskania wiążącego rozstrzygnięcia). Wskazany zakres interpretacji prawa do sądu uzupełniony został zgodnie z wykładnią Trybunału Konstytucyjnego określeniem prawa do odpowiedniego kształtowania ustroju i pozycji organów rozpoznających sprawy (w odniesieniu do państwowego wymiaru sprawiedliwości) $^{14}$. Zgodnie przy tym z interpretacją Trybunału Konstytucyjnego przyjmuje się, że w państwie prawnym prawo do sądu nie może być rozumiane jedynie formalnie, jako dostępność drogi sądowej w ogóle, lecz i materialnie, jako możliwość prawnie skutecznej ochrony praw na drodze sądowej i w związku z tym naruszenie prawa do sądu może nastąpić poprzez nadmierny formalizm procesowy i może być wynikiem działania (kumulatywnie lub indywidualnie) ustawodawcy lub przedstawicieli praktyki, w tym przede wszystkim organów wymiaru sprawiedliwości ${ }^{15}$. Powszechnie również akceptowane jest stanowisko wskazujące, że gwarancje konstytucyjne związane z prawem do sądu nie mogą być traktowane jako nakaz urzeczywistnienia $\mathrm{w}$ każdym trybie i w każdym rodzaju procedury tego samego zestawu instrumentów procesowych, jednolicie określających pozycję stron postępowania i zakres przysługujących im środków procesowych i stąd nie każda odmienność lub specyfika postępowania sądowego musi być a priori traktowana jako ograniczenie prawa do sądu i związanych z tym gwarancji procesowych stron ${ }^{16}$.

W kontekście przytoczonych poglądów i wykładni konstytucyjnego prawa do sądu wskazuje się w doktrynie, że poddanie sprawy pod rozstrzygnięcie sądu arbitrażowego jest wypadkiem dopuszczalnej z konstytucyjnego punktu widzenia rezygnacji z prawa do rozpoznania sprawy przez sąd państwowy w ramach ochrony udzielanej przez państwo ${ }^{17}$. Przeciwny pogląd, wyłączający możliwość zrzeczenia się prawa do sądu, wskazuje, że oddanie sporu pod rozstrzygnięcie sądu polubownego nie stanowi rezygnacji z prawa do sądu, ponieważ $\mathrm{w}$ żadnej mierze nie wyłącza kontroli sądu polubownego przez sąd powszechny ${ }^{18}$. Inny z kolei pogląd bazuje na stwierdzeniu, że prawo do sądu realizowane jest przez sąd polubowny ${ }^{19}$, bowiem prawo do sądu należy rozumieć jako prawo do uruchomienia procedury przed sądem będącym organem o określonych cechach takich

14 Por. uzasadnienie wyroku Trybunału Konstytucyjnego z dnia 24 października 2007 roku, SK 7/06, OTK-A z 2007 r. nr 9, poz. 108.

15 Por. uzasadnienie wyroku Trybunału Konstytucyjnego z dnia 20 maja 2008 roku, P 18/07, OTK-A z 2008 r. nr 4, poz. 61.

16 Por. uzasadnienie wyroku Trybunału Konstytucyjnego z dnia 16 listopada 2011 roku, SK 45/09, OTK-A z 2011 r. nr 9, poz. 97.

17 T. Ereciński, K. Weitz, op. cit., s. 21-22.

18 Ł. Błaszczak, M. Ludwik, op. cit., s. 52-55.

19 R. Morek, ADR - alternatywne metody rozwiazywania sporów w sprawach gospodarczych, Warszawa 2004, s. 40-52. 
jak niezależność i bezstronność ${ }^{20}$. Z przytoczonych stanowisk doktryny wynikają więc zasadniczo trzy rozbieżne stanowiska, które w odniesieniu do sporządzenia zapisu na sąd polubowny można ogólnie określić jako rezygnację z prawa do sądu, wykluczenie tej rezygnacji czy też realizację prawa do sądu w ramach sądownictwa polubownego przy zachowaniu wymogu niezależności sądów polubownych.

Zwolennicy poszczególnych koncepcji przytaczają dodatkowe argumenty, które łagodzą nieco skrajność stanowisk i pozwalają na nieznaczne zbliżenie poglądów odnoszących się do realizacji prawa do sądu w ramach sądownictwa polubownego. Wskazuje się, że rezygnacja z prawa do sądu nigdy nie może być rozumiana jako całkowita i definitywna, gdyż funkcjonowanie sądownictwa polubownego określone zostało w obowiązujących regulacjach w ramach zbliżonych do sądowego wymierzania sprawiedliwości, nadto orzeczenia sądów polubownych podlegają kontroli sądów państwowych. Podnosi się przy tym, że kontrola i nadzór nad sądownictwem polubownym sprawowane są z mocy obowiązujących regulacji, których strony nie mogą uchylić ani zmienić mocą uzgodnień czynionych przy zawieraniu umowy arbitrażowej. Ponadto właśnie realizacja czynności kontrolnych nad sądownictwem polubownym gwarantuje realizację konstytucyjnego prawa do sądu, które należy rozumieć nie jako oddanie sporu pod rozstrzygnięcie organu pozasądowego, lecz możliwość prowadzenia postępowania i rozstrzygania przez sąd polubowny $\mathrm{z}$ zagwarantowaną $\mathrm{w}$ ramach sprawowania wymiaru sprawiedliwości adekwatną sądową kontrolą rozstrzygnięć sądu polubownego. Wskazanie natomiast na realizację $\mathrm{w}$ ramach sądownictwa polubownego konstytucyjnego prawa do sądu odnoszone jest do możliwości podejmowania $\mathrm{w}$ toku czynności procesowych wszelkich działań prowadzących do alternatywnego rozwiązania sporu sądowego. W odniesieniu do tak rozumianego prawa do sądu dopuszcza się więc realizację wszelkich postępowań negocjacyjnych, mediacyjnych, arbitrażowych, które nie wykluczają prawa obywatela do sądu, a przeciwnie gwarantują realizację tego prawa w ramach akceptowanego przez strony alternatywnego rozwiązania bądź rozstrzygnięcia sporu. Istotne rozbieżności poglądów odnoszących się do ewentualnej całkowitej lub częściowej rezygnacji z prawa do sądu, czy też interpretacja ograniczenia prawa do sądu jako faktyczna realizacja tej zasady wykluczają możliwość polaryzacji stanowisk w zakresie oceny funkcjonowania sądownictwa polubownego w odniesieniu do określonej w art. 45 ust. 1 i art. 77 ust. 2 Konstytucji zasady gwarantującej obywatelom prawo dostępu do sądu. W odniesieniu do przedstawionych poglądów doktryny oraz uwag dotyczących rozbieżnych interpretacji i ocen funkcjonowania sądownictwa polubownego względem konstytucyjnej zasady prawa do sądu na szczególną uwagę zasługuje

${ }^{20}$ M. Romanowski, Znaczenie niezależności i bezstronności arbitra w postępowaniu arbitrażowym w świetle konstytucyjnego prawa do sadu, [w:] Księga pamiątkowa..., s. $376 \mathrm{n}$. 
koncepcja oparcia regulacji prawnej arbitrażu na zasadzie konstytucyjnej autonomii podmiotów ${ }^{21}$.

Określona w art. 31 Konstytucji w zw. z art. 5 i art. 7 Konstytucji zasada wolności (autonomii) jednostki koresponduje z przysługującą stronom umowy arbitrażowej wolnością oddania sporu do rozstrzygnięcia sądowi prywatnemu ${ }^{22}$. Zasada podlegania ochronie prawnej wolności człowieka stanowi z jednej strony skierowany do ustawodawcy nakaz stworzenia gwarancji i wolności w poszczególnych regulacjach, $\mathrm{z}$ drugiej strony pozwala na określenie w przepisach nakazów i zakazów określających granice tej wolności. Konstytucyjnie określona zasada ochrony i poszanowania wolności człowieka niewątpliwie tworzy autonomiczną sferę wolną od jakiejkolwiek ingerencji zarówno ze strony innych podmiotów, jak i władz publicznych. Gwarantowana więc konstytucyjnie autonomia praw i wolności obejmuje również prawo do powierzania wybranej osobie trzeciej rozstrzygnięcia sporu o prawo podmiotowe, co z kolei skutkuje obowiązkiem ustawodawcy określenia w systemie prawnym właściwych przepisów regulujących zasady funkcjonowania arbitrażu. Podkreślić przy tym należy, że w odniesieniu do wskazanego prawa wyboru sposobu rozstrzygnięcia sporu odpowiednio w zetknięciu z konstytucyjną zasadą prawa do sądu, to właśnie zasada wolności jednostki powinna mieć w niezbędnym dla jej realizacji zakresie pierwszeństwo ${ }^{23}$. Nadmienić przy tym należy, że możliwość powstania kolizji norm konstytucyjnych i wynikającą stąd konieczność ograniczenia zakresu przedmiotowego prawa do sądu potwierdzona została w orzecznictwie Trybunału Konstytucyjnego ${ }^{24}$.

Koncepcja pierwszeństwa zasady autonomii praw i wolności jednostki jako podstawowej i kształtującej prawa podmiotowe pozwala zatem na pogodzenie z pozoru różnych zakresów gwarancji prawa do sądu i gwarancji skuteczności zapisu na sąd polubowny. Zasada zagwarantowania prawa do sądu niewątpliwie ma również na celu gwarancję realizacji praw podmiotowych jednostek, ale nie może przy tym wyłączać autonomii wolności wyboru najbardziej dogodnego i akceptowanego przez strony rozstrzygnięcia sporu przed sądem polubownym. W ramach zatem autonomii wolności i praw jednostki pozostaje zarówno swoboda sporządzenia zapisu na sąd polubowny, jak też realizacja czynności w ramach postępowania arbitrażowego celem rozstrzygnięcia sporu przez sąd polubowny. Zgodnie z dyspozycją art. 31 ust. 1 i 3 Konstytucji ustawodawca precyzyjnie określił obowiązującymi przepisami granice autonomii wolności w odniesieniu do sądownictwa polubownego przez wprowadzenie obowiązkowej treści i formy zapisu na sąd

21 A.W. Wiśniewski, Konstytucyjne podstawy arbitrażu, [w:] Konstytucjonalizacja postępowania cywilnego, red. Ł. Błaszczak, Wrocław 2015, s. 353 n.

22 A.W. Wiśniewski, Międzynarodowy arbitraż handlowy w Polsce, Warszawa 2011, s. 71-72.

23 Ibidem, s. 68.

24 Por. uzasadnienie wyroków Trybunału Konstytucyjnego z dnia 9 czerwca 1998 roku, K 28/97, OTK z 1998 r. nr 4, poz. 50 oraz z dnia 16 marca 1999 roku, SK 19/98, OTK z 1999 r. nr 3, poz. 36 . 
polubowny, określenie sposobu i zasad prowadzenia postępowania arbitrażowego czy też sprecyzowania podstaw uchylenia bądź odmowy uznania, lub stwierdzenia wykonalności wyroku sądu polubownego. Warto przy tym zaakcentować, że sprecyzowane we właściwych przepisach wymogi, warunki i przesłanki dotyczące prawidłowości sporządzenia zapisu na sąd polubowny oraz prowadzenia i rozstrzygania sporu przed sądem arbitrażowym przewidują ograniczenia w zakresie korzystania z konstytucyjnej wolności na poziomie gwarantującym autonomię wolności jednostki, ale również ochronę wolności i praw innych osób, a nawet zagwarantowanie ochrony porządku prawnego w ramach sądowej kontroli wyroku sądu polubownego.

\section{PODSUMOWANIE}

Analiza konstytucyjnych aspektów arbitrażu pozwala na stwierdzenie, że funkcjonowanie sądownictwa polubownego pozostaje w zgodzie z podstawowymi zasadami konstytucyjnymi. Określone w Konstytucji zasady gwarantujące obywatelom prawo dostępu do sądu oraz autonomii praw i wolności w pełni korespondują z przewidzianą obowiązującymi przepisami możliwością zarówno sporządzenia zapisu na sąd polubowny, jak i zawarcia umowy kompromisarskiej celem poddania sporu pod rozstrzygniecie sądu polubownego.

Sądownictwo państwowe uzupełnione sądownictwem polubownym można określić jako nowoczesną przestrzeń sądowej sprawiedliwości realizującą konstytucyjnie gwarantowane prawo do sądu rozumiane nie tylko jako prawo dostępu do sądu czy prawo do ukształtowania procedury sądowej zgodnie z wymaganiami sprawiedliwości, ale również jako prawo do wiążącego rozstrzygnięcia danej sprawy ${ }^{25}$. Prawo do ochrony prawnej realizowane w ramach wolności i swobody poddania sporu pod rozstrzygnięcie sądu polubownego pozostaje przy tym gwarantowane wzajemnie uzupełniającymi się relacjami sądownictwa państwowego i sądownictwa polubownego. Nowoczesne rozstrzyganie sporów obok profesjonalizacji czynności w ramach postępowań sądowych wymaga przede wszystkim kształtowania wzajemnych relacji sądownictwa państwowego i sądownictwa polubownego $\mathrm{w}$ ramach poszukiwania metod pozasądowego rozwiązywania sporów. W tym kontekście słuszne wydają się postulaty współpracy i współdziałania w relacjach wzajemnego zaufania instytucji sądowego rozstrzygania sporów celem rozpowszechniania, popularyzacji i propagowania arbitrażu. Istotne mogą się przy tym okazać wzorce stosowania klauzul arbitrażowych w międzynarodowym obrocie handlowym i odpowiednie wykorzystywanie sądownictwa polubownego do rozstrzygania sporów w ramach krajowego profesjonalnego obrotu handlowego,

25 Por. uzasadnienie wyroku Trybunału Konstytucyjnego z dnia 17 października 2010 roku, SK 5/99, OTK z 2000 r. nr 7, poz. 254. 
zwłaszcza w sprawach z elementem transgranicznym oraz o znacznej wartości przedmiotu sporu.

Sądownictwo polubowne, mimo usytuowania arbitrażu poza konstytucyjnie zdefiniowanym wymiarem sprawiedliwości, może okazać się istotnym uzupełnieniem państwowego wymiaru sprawiedliwości przez zapewnienie realizowanej w ramach arbitrażu ochrony prawnej — wyjątkowej przez pryzmat współczesnych koncepcji rozstrzygania sporów. Wobec bieżących krytycznych ocen funkcjonowania sądownictwa powszechnego warto zatem rozważyć, w ramach konstytucyjnie gwarantowanych praw i wolności, wyłączenie zapisem na sąd polubowny jurysdykcji sądownictwa państwowego i poddanie sporu pod rozstrzygniecie sądownictwa prywatnego przy uwzględnieniu w szczególności walorów sądownictwa polubownego i zalet rozstrzygania sporów w ramach arbitrażu.

\section{ARBITRATION JUDICIARY - CONSTITUTIONAL ASPECTS OF ARBITRATION}

\section{Summary}

Arbitration, despite being located outside the constitutionally defined judiciary, may turn out to be a significant complement to it. The applicable regulations allow, in exercise of the freedom of contract, to exclude the jurisdiction of state courts by an arbitration agreement in order to resolve the matter by an arbitration court. The possibility of resolving disputes in the framework of arbitration by granting arbitration courts the status of legal protection bodies is widely accepted. The Constitution of the Republic of Poland defines the principles guaranteeing citizens the right of access to a court and the autonomy of rights and freedoms - does the functioning of arbitration comply with the basic constitutional principles, in particular by the perceiving arbitration in terms of private courts and referring to the constitutionally guaranteed justice system? The answer is affirmative, taking into account that the state judiciary supplemented by arbitration is perceived as shaping a modern judicial area of justice.

Keywords: arbitration judiciary, arbitration, constitution, dispute resolution, conflict resolution, administration of justice

\section{BIBLIOGRAFIA}

Błaszczak Ł., Ludwik M., Sadownictwo polubowne (arbitraż), Warszawa 2007.

Budniak-Rogala A., Charakter prawny zapisu na sąd polubowny w postępowaniu cywilnym, Wrocław 2015.

Czeszejko-Sochacki Z., Prawo do sądu w świetle Konstytucji Rzeczypospolitej Polskiej. (Ogólna charakterystyka), „Państwo i Prawo” 1997, nr 11-12.

Ereciński T., Weitz K., Sąd arbitrażowy, Warszawa 2008.

Garlicki L., Polskie prawo konstytucyjne. Zarys wyktadu, Warszawa 2000. 
Gil P., Delegowanie funkcji orzeczniczych na podmioty spoza systemu wymiaru sprawiedliwościkonstytucyjne granice instytucji, [w:] Konstytucjonalizacja postępowania cywilnego, red. Ł. Błaszczak, Wrocław 2015.

Gołaczyński J., Krzywonos A., Prawo do sądu, [w:] Prawa i wolności obywatelskie w Konstytucji $R P$, red. B. Banaszak, A. Preisner, Warszawa 2002.

Marszałkowska-Krześ E., Kodeks postepowania cywilnego. Komentarz, Warszawa 2015.

Mądrzak H., Prawo do sąu jako gwarancja ochrony praw człowieka (studium na tle polskiego prawa konstytucyjnego, prawa cywilnego materialnego i procesowego), [w:] Podstawowe prawa jednostki i ich sadowa ochrona, red. L. Wiśniewski, Warszawa 1997.

Morek R., ADR - alternatywne metody rozwiązywania sporów w sprawach gospodarczych, Warszawa 2004.

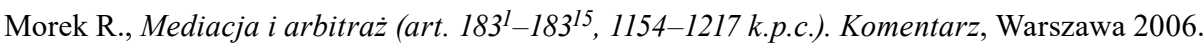

Okolski J., Arbitrażu nie wolno sformalizować, „Puls Biznesu” 3.02.2005.

Romanowski M., Znaczenie niezależności i bezstronności arbitra w postępowaniu arbitrażowym w świetle konstytucyjnego prawa do sąu, [w:] Księga pamiatkowa 60-lecia Sadu Arbitrażowego przy Krajowej Izbie Gospodarczej w Warszawie, red. J. Okolski et al, Warszawa 2010.

Skoczylas J., Charakter prawny zapisu na sad polubowny a autonomia regulacji prawnej arbitrażu (po nowelizacji z 2005 roku), [w:] Księga pamiatkowa 60-lecia Sądu Arbitrażowego przy Krajowej Izbie Gospodarczej w Warszawie, red. J. Okolski et al, Warszawa 2010.

Wiśniewski A.W., Konstytucyjne podstawy arbitrażu, [w:] Konstytucjonalizacja postępowania cywilnego, red. Ł. Błaszczak, Wrocław 2015.

Wiśniewski A.W., Międzynarodowy arbitraż handlowy w Polsce, Warszawa 2011. 